\title{
8. Recent Developments in Higher Education in Indonesia: Issues and challenges
}

\author{
Teguh Yudo Wicaksono and Deni Friawan \\ Centre for Strategic and International Studies, Indonesia
}

\section{Introduction}

Secular higher education in Indonesia has a relatively short history. It began with the establishment by the Dutch colonialists of tertiary schools training indigenous people in medicine and engineering. Before the colonial education system, higher education was considered an Islamic institution. The growth in higher education post independence has, however, been very swift. Since the endorsement of the very first Education Act in 1961, Indonesian higher education has continuously experienced rapid expansion. The development of higher education grew during the period from the 1970s to the 1990s, when Indonesia was experiencing strong economic growth, fuelled by an oil-price boom and solid non-oil and gas export performance. Nizam (2006) recorded that the student population in higher education institutions (HEIs) increased from about 200000 students in 1975 to 2.5 millions students in 1995. By 2005, there were nearly 2300 HEIs, consisting of 86 public HEIs and about 2200 private HEIs. More than 3.5 million students were educated in these HEIs.

Though this rosy trend gives a good signal, some observers addressed crucial problems behind the growing HEIs. Moeliodihardjo et al. (2000), for example, argue that the rapid expansion of HEIs has not been in parallel with appropriate planning and funding mechanisms. The higher education system has suffered internal inefficiency and poor initiatives due to a centralised education system. In addition, the bureaucratic dependency on a central authority has made HEIs (particularly public HEIs) unable to respond to external changes or receive appropriate support (Nizam 2006). Further, the public HEIs have lacked any sense of public accountability, as, according to a bureaucratic structure, they are part of the institution of government under the Ministry of National Education.

Consequently, the absence of any autonomy and the diminished sense of community in HEIs have resulted in a lack of accountability and responsibility to society (World Bank 1996). This has had an adverse impact on the quality, efficiency and relevance of higher education in Indonesia. The poor quality 
of higher education can be seen from the low levels of qualification of the teaching staff, inadequate laboratory facilities (especially in the private HEIs) and limited library holdings. Meanwhile, low efficiency is best demonstrated by the extended enrolment period in which a typical undergraduate - in both public and private HEIs - spends about five to six years completing their studies instead of the four years required. Low internal efficiency can also be seen from the low student-teacher ratios of about 12:1, limited utilisation of physical space, and the low number of student/staff contact hours.

As far as public financing is concerned, it has long been recognised that the government is facing strained resources to support higher education. Before the economic crises hit the country, higher education was not a top priority in education policy. This is understandable, as the country is still struggling to achieve its nine-year compulsory education policy (primary and junior high school), which consumes a large amount of resources. The financial crisis has aggravated critical conditions for HEIs, particularly public HEIs that rely mostly on the government for support. Public HEIs have to compete for public resources not only with primary education but also with other social sectors and issues such as health, poverty alleviation and social security.

This recent study is an attempt to outline the main characteristics of the higher education sector in Indonesia and review major policy developments affecting the financial mechanism and the delivery of tertiary education over the past few decades. It will pay particular attention to the effective roles of government-funding schemes and types of student loan arrangements in the broader policy setting.

This chapter will discuss the evolution of the structure of institutions of higher education in Indonesia. It focuses on the access to and equality of higher education services, and reviews several issues related to the financing mechanisms of higher education in Indonesia, including the general trend and composition of public expenditure, the sources of funds, and the impact of the economic crisis and decentralisation on the allocation of finances.

\section{Overview of Higher Education in Indonesia: Structure, institution and type}

\section{The Evolution of the Structure of Institutions}

Indonesian higher education witnessed a massive expansion in tertiary education post independence. In the colonial period, there were very few HEIs in the country. These institutions were designed to provide professional training to local people mainly in the areas of medicine and engineering. Academic and research programs were not established in this time. Due to the social stratification 
in colonial times, there were students only from elite groups enrolled in universities. It is estimated that only 200 students enrolled in universities in the colonial period (KJPP 2003). Post independence, the political climate and the national spirit have meant the country aspired to have at least one public university in each province. About 23 new HEIs were established during the 1960s, and these institutions covered almost 26 provinces in Indonesia (Nizam 2006). This policy has brought higher education to a mass scale.

Another important point in the 1960s was the enactment of the first education law-Law No. 15 of 1961 — which detailed the structure for higher education. Under the law, universities have a standardised division of faculties and structure of governance (Buchori and Malik 2004). The law defines the mission of HEIs and details the 'Tri Dharma Perguruan Tinggi' (Three Pillars of National Higher Education): learning, research and community service. The law also encouraged diversification in higher education programs. Before the endorsement of the law, private HEIs were not recognised as part of the national education system. With the implementation of the law, private HEIs, along with public HEIs, were standardised and brought in as part of the national education system. This provision has encouraged private HEIs to flourish around the country.

The demand for education increased in the 1970s, which corresponded with a shift in the economy from the traditional sector to a more modernised one. Indonesia's economy experienced high economic growth thanks to an accelerating process of industrialisation in the export industry. This process led to mounting demand for skilled workers, particularly science and technology graduates. As the government could provide only limited support for higher education, in 1975, it made considerable changes to the higher education system.

In 1975, the Ministry of Education through the Directorate-General of Higher Education (DGHE) established a framework for the development of higher education. This framework worked as a basic guide to standardise the national higher education system. It covered the structure of academic programs (undergraduate and graduate), governance, and the roles and responsibilities of faculty members.

A dual system - academic and vocational - was also initiated in the same period. According to the framework, academic programs consist of a four-year undergraduate degree (strata 1-S1), two-year Master's level (strata 2, S2) and a three-year doctorate program (Strata 3-S3). Vocational programs offer one to four-year non-degree training places.

It could be argued that these considerable changes taken by the DGHE were influenced by the end of European or continental influence in Indonesia's higher education system. By the end of the 1970s, the government adopted the USstyle system of including the accumulation of credit points in the curriculum. 
A student of a three-year diploma program is required to complete 110 to 120 credit units. A student of an undergraduate degree (s1) has to complete 144 to 160 credit units. This significant change could be attributed to the large number of faculty members and bureaucrats who studied in the United States. The credit system is also more desirable as it monitors student performances easily and reduces the length of study. This shift in the education system sent a signal that the government valued the role of HEIs in creating skilled workers and responding to labour-market changes.

In 2003, the House of Representatives endorsed a new education law-Law No. 202003 - which also outlines the structure and purpose of HEIs. The new law essentially adopts the same groundwork for the higher education system; however, it provides greater autonomy to HEIs than the previous law.

\section{The Types of Higher Education in Indonesia}

The higher education system cannot be analysed separately from Indonesia's entire education system. Figure 8.1 illustrates the organisational structure of the country's education system. Recently, the organisational structure of the school system was separated into two streams: the Islamic stream under the Ministry of Religious Affairs (public and private), and the secular stream under the Ministry of National Education (public and private). These two steams are separated over three levels of education: basic education, middle or secondary education, and higher education.

Children are not required to go to preschool, however, the government makes every effort to encourage parents to send their children to preschool before entering them into elementary schools. In May 1994, the President of the Republic of Indonesia affirmed that basic education in Indonesia included nine years of compulsory schooling. The basic education includes six years of elementary school and three years of junior secondary school. Middle or secondary education includes three years of general senior secondary school or vocational senior secondary school.

Higher education is an extension of secondary education. The Indonesian higher education system consists of academic and professional learning. Academic education is designed at mastering science, technology and research. Professional education is aimed at developing practical skills. The institutions providing higher education are categorised into universities, institutes, collages, academies, and polytechnics in both the public and the private sectors. 


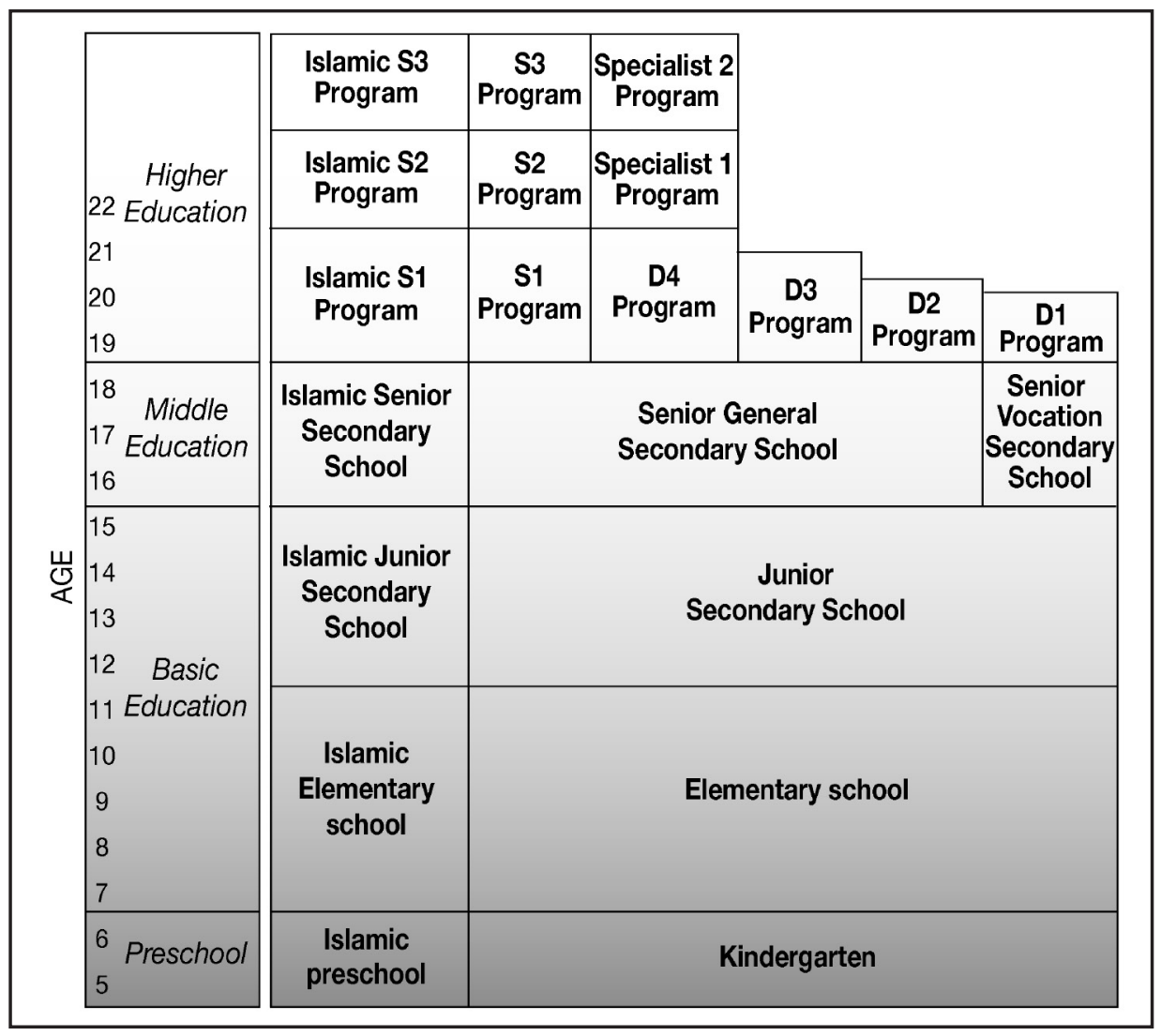

Figure 8.1 School system in Indonesia

Source: Mohandas (2004).

In addition, a university consists of several faculties conducting academic and/or professional education in several disciplines. An institute consists of faculties conducting academic and/or professional education in disciplines that align with a set profession. In comparison, a college conducts academic and professional education in one particular discipline. Meanwhile, an academy and a polytechnic are vocational HEIs that provide professional skills and diploma degrees.

Based on their status, the HEIs in Indonesia can be divided into two groups: the public HEIs and the private HEIs. The public HEIs are under the jurisdiction of the state treasury law, education system law and civil servant law and are treated as part of the ministry. Private HEIs are regulated under the Foundation and Education System Law, and are considered the business arm of the foundation. Brodjonegoro (2000) argues that, under these regulations, the HEIs have no independent means of carrying out their mission as a moral force and they become less accountable and less innovative. 
There is also a difference in the admissions processes. The admission process in public HEIs is done through the national examination for higher education (Seleksi Penerimaan Mahasiswa Baru). As seats in public HEIs are limited, a prospective applicant has to compete nationally for a specific field. Usually the applicant submits for acceptance to two to three prospective programs. This system ensures that only those with the highest scores are admitted. Admission into private HEIs is considered to be less competitive. As several private HEIs have a very good reputation, admission to these institutions is, however, as competitive as it is for public HEIs.

\section{The Recent Issues of Higher Education in Indonesia}

\section{Access and Equality}

As in many places, in Indonesia, equality in education has become a hotly debated issue, particularly in regard to higher education. There are several reasons that could explain this. The first is due to a common perception that higher education is a public good. Second, the function of higher education is to train future elite groups who will be an important part of the country's development, which has led HEIs to be politico-imperative educational institutions. History shows that critical moments in Indonesia's political and economic progress were strongly linked to the roles of HEIs. Indonesia's independence movement, for example, was prompted mainly by well-educated young Indonesians. Political turbulence in the country was closely related to the political activities of university students. Therefore, graduates of HEIs carry high social status. The third reason for inequality in education is the expectation of graduates in the job market. Graduates are expected to enjoy well-paid jobs and work in the formal sector, whose members are considered better off than those in the informal sector. Therefore, there is a strong political aspiration to produce opportunities in higher education for all groups in society.

Although higher education has expanded rapidly in the post-independence era, the growth in supply of HEIs still does not meet the growing demand. Meanwhile, the government's ability to expand the supply of public HEIs is constrained by the budget, and the fact that the private sector has dominated the tertiary education market for the past 20 years. Most private HEIs, however, rely on student fees in running their institutions, which means they are quite expensive for those who come from a disadvantaged background. As such, participation rates in higher education have been low for years. 
Recent data gathered by the National Socio-Economic Survey (Survei Sosio-Ekonomi Nasional; Susenas) of Badan Pusat Statistik (BPS; Central Statistics Agency) shows that the enrolment rate in higher education is quite low in Indonesia. It is worth noting, however, that Susenas data might underestimate the numbers enrolled in tertiary education in Indonesia. This might be due to the fact that a large proportion of students are from middle-high-income households, while those from an upperclass background are not included in the data.

Another issue with the data is demographic mobility. It is likely that Susenas does not sample students who are still living with their parents. Also, the sampling method of Susenas excludes students who live in boarding houses (off-campus and on-campus). This is due to the sampling guide of Susenas for which a person who lives in a boarding house, military barracks or prison will not be surveyed. Despite this, Susenas data are the best available considering the sample size and national coverage.

By 2006, the gross enrolment rate ${ }^{1}$ (GER) in tertiary education reached only 12.16 per cent. Figure 8.2 illustrates that, during 1993-2003, the GER in higher education tended to stagnate. The economic crisis that hit the country in 1998 seemed to have no strong effect on the enrolment rate. Generally, a low participation rate indicates high inequality of access to HEIs. This presumption is confirmed by Figure 8.3.

According to Susenas, the GER of students from a low-income family background was about 0.63 per cent in $1993 .^{2}$ This was far lower than the enrolment rate of students from the top 20 per cent bracket of income per capita household (about 27.78 per cent in the same year). After more than a decade, the gap has not narrowed significantly. In 2006, the number of low-income students enrolled in tertiary education was 2.67 per cent. This number was still far lower than that for students from the top 20 per cent income bracket (about 33.9 per cent).

\footnotetext{
1 The GER of tertiary education is the ratio of all tertiary school students to all tertiary school-aged people (nineteen-twenty-four). The age range (nineteen-twenty-four years old) is based on BPS's definition. Even though this range covers only undergraduate-aged persons and ignores graduate-aged persons, this approach is still appropriate and convenient considering the very low number of people going in at graduate level.

2 Low income means the 40 per cent lowest expenditure per capita distribution. In this context, we assume that household expenditure will be a good proxy for household income. Regarding expenditure itself, it is the current household expenditure per capita of the student (total expenditure is divided by the number of household members regardless of the age of the members).
} 


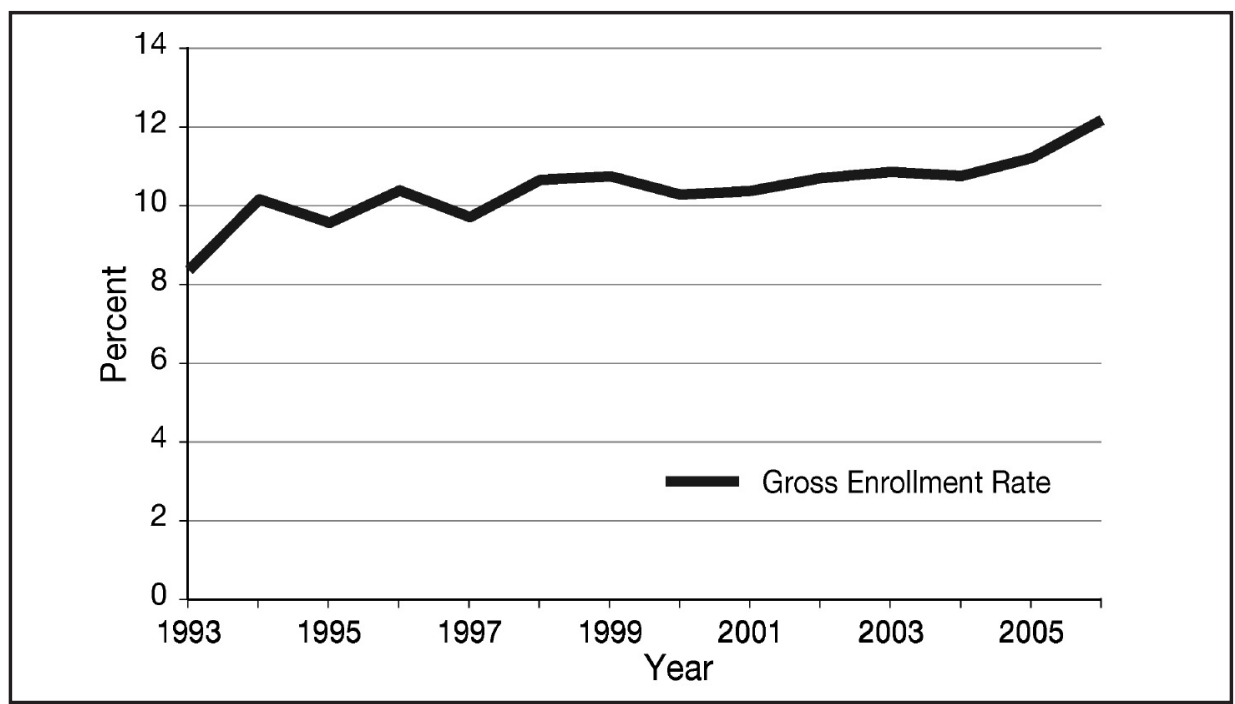

Figure 8.2 Gross enrolment rate in higher education

Source: National Socio-Economic Survey (Susenas) 1993-2006.

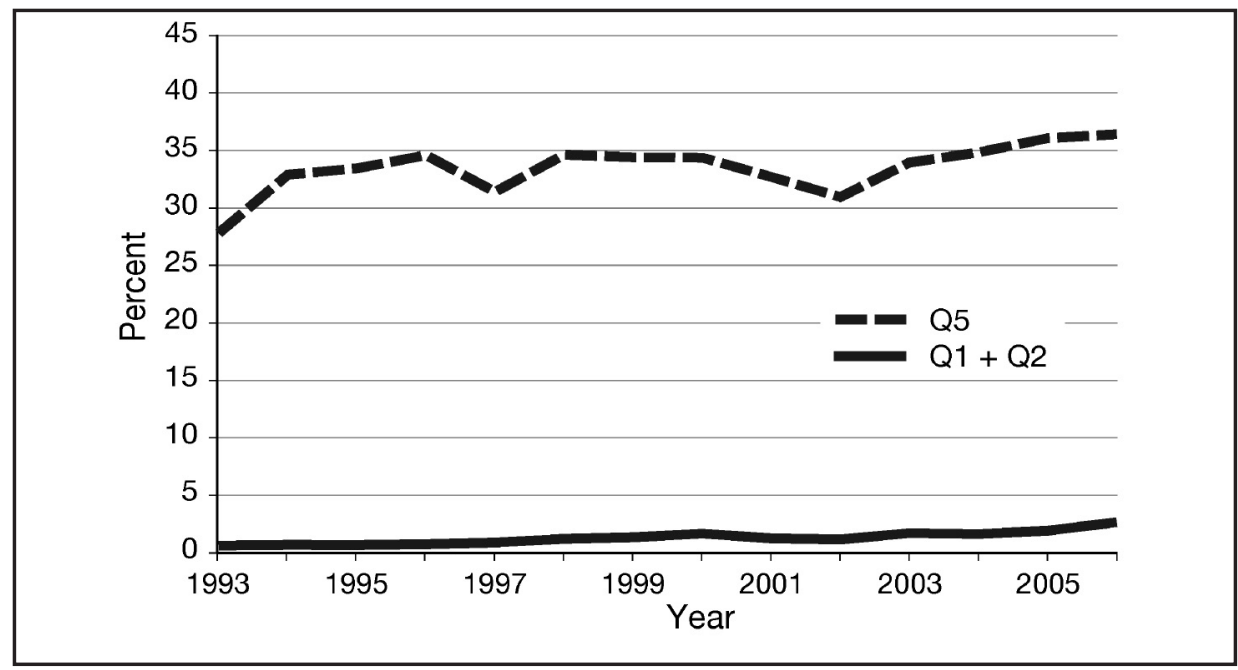

Figure 8.3 Gross enrolment rate in higher education by income group

Source: National Socio-Economic Survey (Susenas) 1993-2006.

We have found that the gender gap in tertiary education has tended to decline in recent years. The trend between 1993 and 2006 shows that the participation rate of females became closer to that of males at a relatively fast pace. In 1993, the female GER was 6.7 per cent and, by 2006, it reached 12.1 per cent - or, it increased proportionally by 81.17 per cent. Meanwhile, the male GER in the same period increased proportionally by only 18.9 per cent in 2006 . 
Interestingly, the gap between the sexes is relatively lower in the low-income group than in the high-income group. Figure 8.3 demonstrates that the average male enrolment rates from both the low-income and the high-income groups ${ }^{3}$ are higher than the female enrolment rates. In terms of progress, however, female participation grew faster than male participation between 1993 and 2006. In 1993, the female GER from low-income families was very small: only 0.46 per cent. This was lower than the GER for males from the same family background, which was about 0.82 per cent. After a decade, female participation in this group had grown rapidly and, by 2006, there was a sixfold increase in the participation rate.

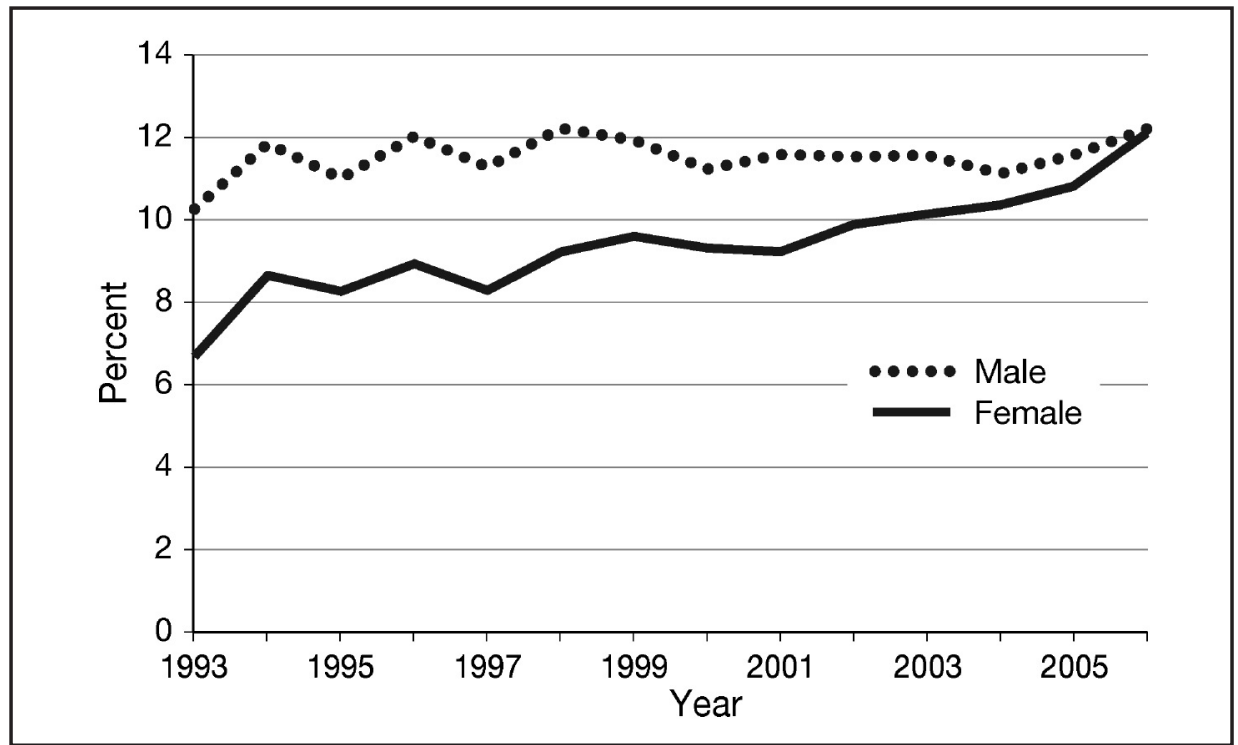

Figure 8.4 Gross enrolment rate in higher education by sex

Source: National Socio-Economic Survey (Susenas) 1993-2006.

Female students from a higher income group have also achieved rapid progress. Within more than a decade, the female GER from the high-income group increased, proportionally, by 49.3 per cent-from 22 per cent in 1993 to 32.8 per cent in 2006. Meanwhile, the male GER grew, proportionally, slower, with 16.6 per cent difference between 1993 and 2006. The relatively low gender gap in participation essentially supports studies arguing that parents rarely discriminate daughters over sons in getting an education, including at the tertiary level. In some cases, discrimination against women within the household can occur due to economic shocks (Oey-Gardiner 1997).

3 The low-income group is defined as the 40 per cent lowest expenditure per capita household; meanwhile, the high-income group is defined as the 20 per cent highest expenditure per capita household. 


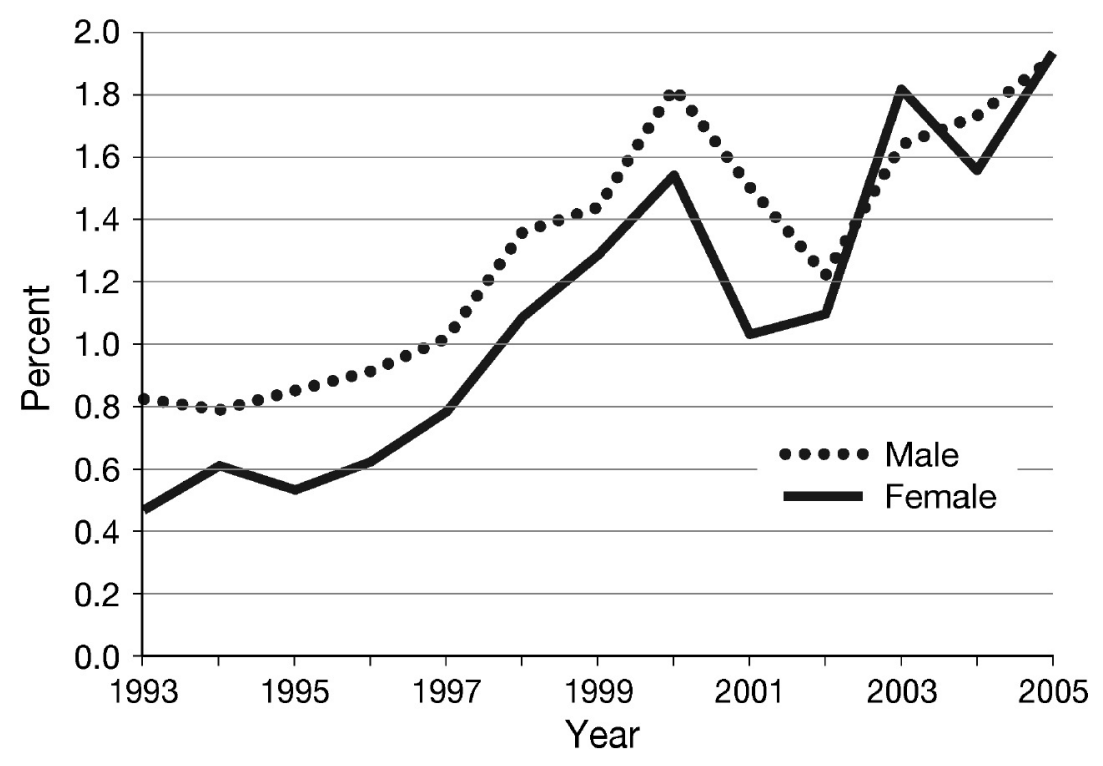

Figure 8.5 Gross enrolment rate: tertiary education of low-income students by sex

Source: National Socio-Economic Survey (Susenas) 1993-2006.

Some education observers argue that a low participation rate at the tertiary level is caused mainly by few HEIs relative to growing demand. Though this argument might sound reasonable, it must be taken with caution. Based on our findings, a low participation rate in higher education is not spurred by supply-side problems. A low participation rate in secondary education and a low continuation rate from secondary education to higher education are the main reasons for a low enrolment rate in tertiary-level education. This suggests that the policy to improve access to higher education cannot be separated from education policies aimed at other educational levels, particularly secondary education. Figure 8.7 shows that there was an upward trend in the GER of senior secondary education between 1993 and 2006. In addition, there was no significant gap in enrolment between males and females. Indeed, the female participation rate in secondary education tended to catch up with the male rate in recent years and this could explain the relatively swift increase of female participation in higher education. 


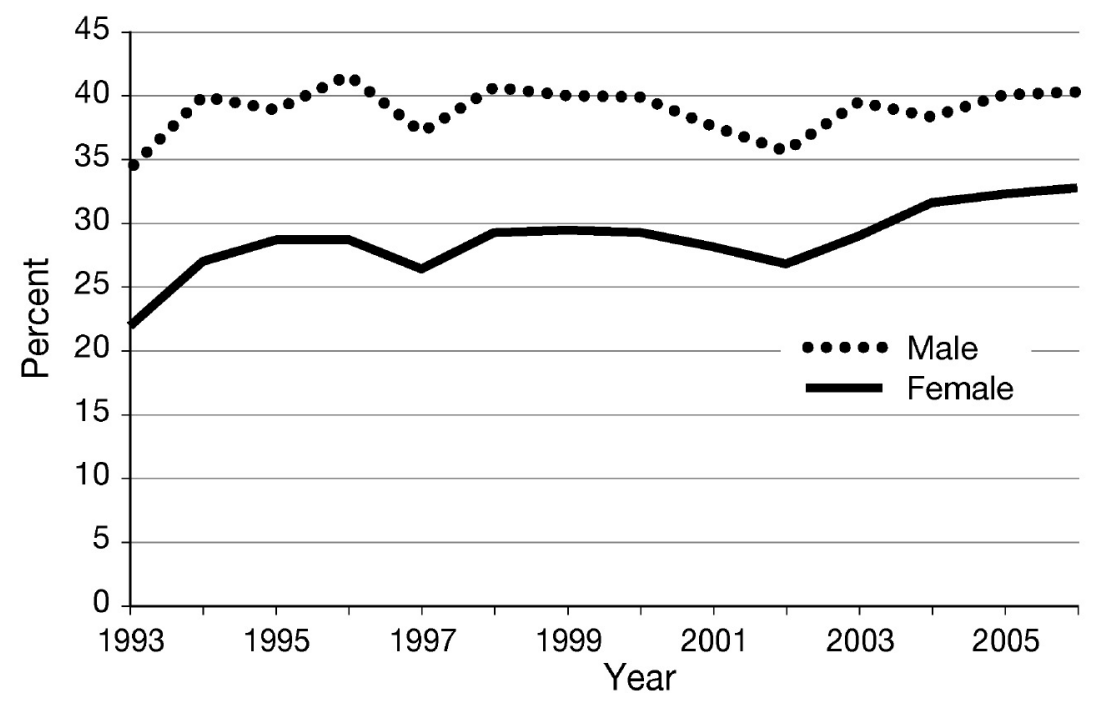

Figure 8.6 Gross enrolment rate: tertiary education of the 20 per cent richest students by sex

Source: National Socio-Economic Survey (Susenas) 1993-2006.

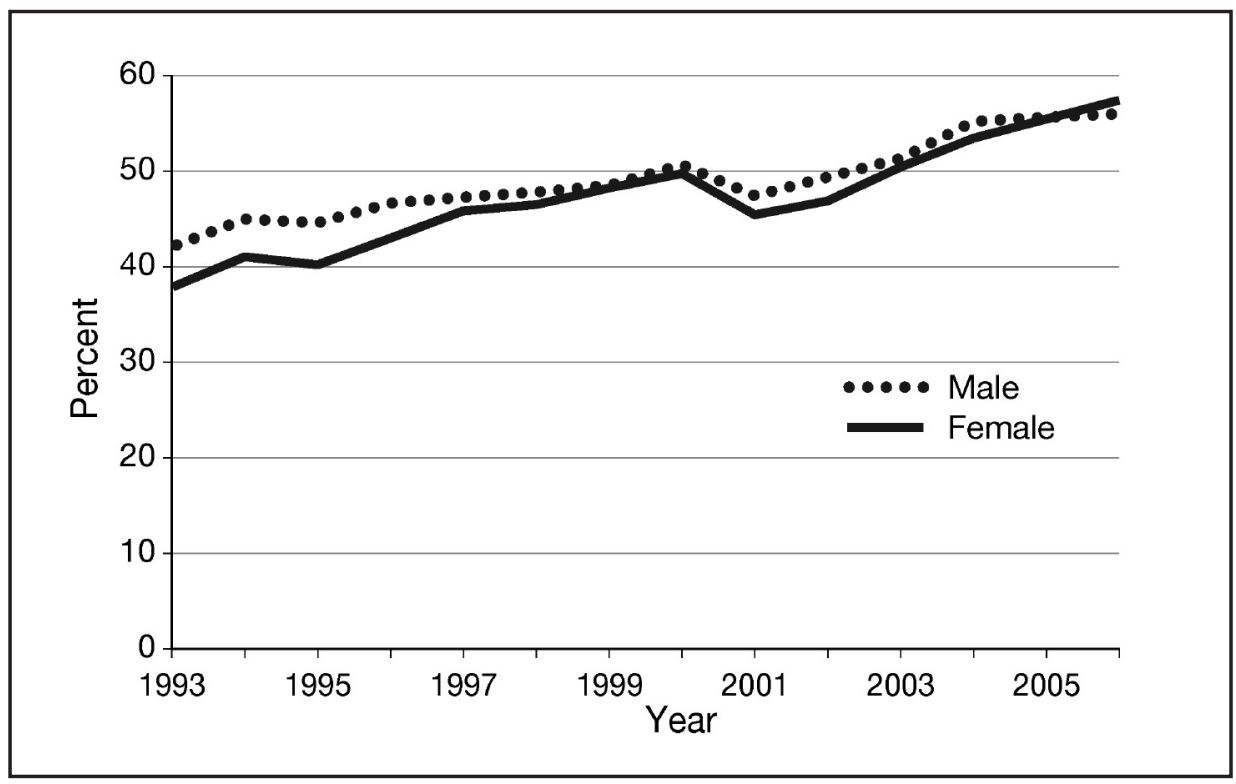

Figure 8.7 Gross enrolment rate in senior secondary education by gender Source: National Socio-Economic Survey (Susenas) 1993-2006. 


\section{Accreditation, Quality Assurance and Research Capacity}

The quality control of HEIs is run through an external and internal accreditation system in Indonesia. The internal accreditation system at some of the more established universities, such as the University of Indonesia and Gajah Mada University, was introduced in the late 1990s as part of a good-practice process within the universities. The quality assurance is run internally and aims to improve the quality of higher education services. Meanwhile, the external accreditation is carried out by the National Education Board for Higher Education (Badan Akreditasi Nasional Perguruan Tinggi; BAN-PT), which was establish in 1994 to conduct academic program assessments and evaluation for both public and private HEIs.

Mandated by the National Education Act No. 2/1989 and Government Regulation on Higher Education No. 60/1999, the BAN-PT is the only accreditation body in Indonesia's higher education system and is based on Ministerial Decree 188/U/1998. The accreditation process was conducted for the first time in 1996, and all programs had to be accredited by BAN-PT by 2001 .

The BAN-PT carries out several functions. The first is to monitor the quality and efficiency of HEIs through the accreditation process in all programs of every institution. The second is to ensure public confidence in the quality of higher education and to guarantee that the quality can be maintained and enhanced. The third is to give recommendations on how study programs can be improved. In order to carry out these functions, the BAN-PT conducts regular quality and efficiency assessment for all HEIs in Indonesia. The assessment covers many aspects: curriculum, the quality and quantity of lectures, student welfare, the institution's facilities and infrastructure, and the management administration. Through the accreditation process, undergraduate and diploma programs are categorised into four levels - from A (satisfactory) to D (unsatisfactory) - while postgraduate programs are categorised into three levels: U (excellent), B (good), and $\mathrm{T}$ (fair). Figure 8.8 describes the flow of the accreditation process carried out by BAN-PT.

According to BAN-PT's report, the quality of many HEIs is still poor. As reported by BAN-PT in 2002, of 6777 programs, 84 per cent were undergraduate programs, 85 per cent of which were categorised as B and C. About 15.73 per cent of public HEIs were accredited A, while only 5.26 per cent of private HEIs were accredited $\mathrm{A}$. This result indicates that the public universities are considerably superior to private HEIs - further reflecting the role of public HEIs as quality leaders and private HEIs as expansion absorbers. 




Figure 8.8 The flow of the accreditation process

Source: BAN-PT.

The low quality of HEIs in Indonesia is caused by the fact that the HEI system has grown so fast there has been no allowance for ensuring high standards for academic staff. As explained by Buchori and Malik (2004), many academic staff in Indonesia's public HEIs have not been well paid. This means that many faculty members at public HEIs dedicate their energy and time to off-campus work: managing or teaching at private HEIs. The conditions in the private HEIs are even worse, as there is a lower proportion of qualified and full-time staff.

In addition, the proportion of staff with higher degrees (Master's or PhD) varies significantly across the sectors. As explained by Nizam (2006), the extensive program of human resource development in the 1980s aimed to develop the research capacity of public universities. Prior to this, most university staff did not have the opportunity to be trained beyond undergraduate level. Mochtar and Buchori (2004) have illustrated that in public HEIs there is only 8.6 per cent of academic staff who hold a $\mathrm{PhD}$ and 29.2 per cent who possess a Master's-level qualification. These statistics are better for public HEIs than for private HEIs. In 2006, the World Bank showed that the difference was almost 300 per cent; only 11 per cent of academic staff in private HEIs were trained beyond their first degree, compared with 30 per cent in public HEIs. As argued by Welch $(1997,1998)$, this was due to few HEIs offering graduate programs and the fact of very low salaries in HEIs compared with other occupations where high-level degrees are needed. 
Recently, the increased funding from the government for the development of human resources has directly generated an increased number of academic staff holding PhDs and Master's degrees. As shown in Figure 8.9, the number of PhDs and Master's from overseas and in-country universities increased in the past decade. During 1996-2000, for example, the number of PhDs and Master's from overseas increased by 32 per cent and 40 per cent, respectively, while the new in-country PhDs also grew significantly and even surpassed those from overseas in 1998. According to the 2000 Directory of Doctors - as seen in Table 8.1about 75 per cent of registered PhDs worked in the four established public HEIs in Java (University of Indonesia, Institut Pertanian Bogor, Institut Teknologi Bandung and University of Gajah Mada). This shows a high disparity of staff qualification between universities on the most-populated island in Indonesia, Java, and outside Java. We need to also consider, however, that 74 per cent of total students in Indonesia are enrolled on Java.

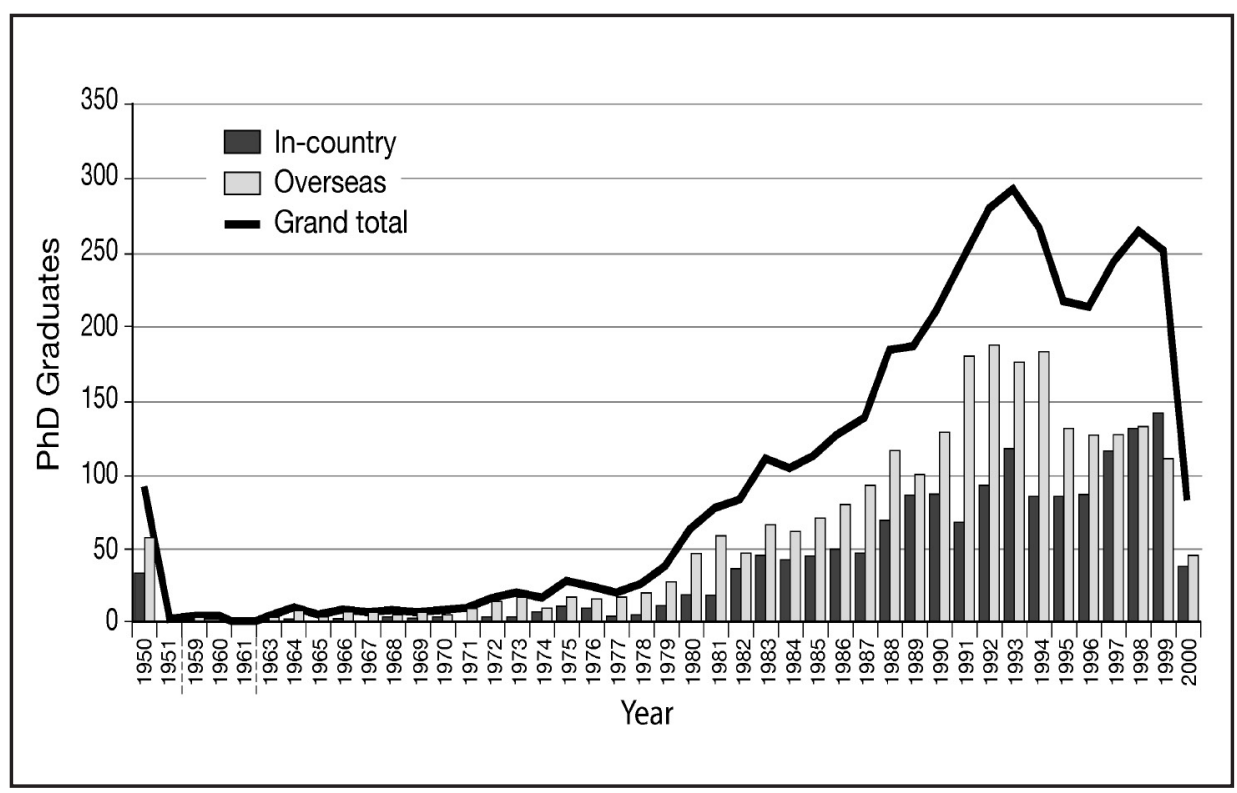

Figure 8.9 The number of new in-country and overseas PhD graduates

Sources: Nizam et al. (2003).

Table 8.1 Distribution of staff with PhDs, 2000

\begin{tabular}{l|r|r|r|r}
\hline \multicolumn{1}{c|}{ Location } & Private & Public & Autonomous & \multicolumn{1}{c}{ Total } \\
\hline Java & $333(9 \%)$ & $1054(28 \%)$ & $1420(38 \%)$ & $2807(75 \%)$ \\
Outside Java & $47(1 \%)$ & $891(24 \%)$ & & $938(25 \%)$ \\
Total & $380(10 \%)$ & $1945(52 \%)$ & $1420(38 \%)$ & $3745(100 \%)$ \\
\hline
\end{tabular}

Source: Directory of Doctors, 2000. 
In addition to the poor quality of teaching staff, the HEIs lack a solid system to support high-quality study programs and research. The quality of Indonesian HEIs, particularly the private HEIs, is weakening due to low staff-student ratios. Welch (2006) shows that staff-student ratios deteriorated in the past few decades. The staff-student ratio decreased from 1:6.6 to 1:10.1 in 1980, to 1:12.4 in 1990, and to $1: 13.7$ in 1998. In the same vein, the quality of HEIs has been reduced due to low investment. Welch (2006) states that the levels of computer equipment and software are 'below the performance standard' for the number of students enrolled.

\section{Trend and Composition of Public Expenditure on Education}

Even though public expenditure on education (in terms of the absolute and the percentage of total national expenditure) increased in recent years, Indonesia's spending on education remains below 20 per cent of total national expenditure. The Constitution obliges the government to spend at least 20 per cent on education. Table 8.2 shows the national public expenditure during 2001-07. This table reveals that both the percentage of national education expenditure to GDP and the proportion of total education expenditure to total national expenditure remained low, despite recent improvements. In 2007, for example, the national education expenditure was only 3.8 per cent of GDP, while it accounted for about 17.2 per cent of total national expenditure.

Table 8.2 National public expenditure (central + province + district), 2001-07 (Rp trillion)

\begin{tabular}{|c|c|c|c|c|c|c|c|}
\hline & 2001 & 2002 & 2003 & 2004 & 2005 & $2006 *$ & $2007 * *$ \\
\hline $\begin{array}{l}\text { Nominal national education } \\
\text { expenditure }\end{array}$ & 40.5 & 48.2 & 64.8 & 61.8 & 74.0 & 118.2 & 135.4 \\
\hline $\begin{array}{l}\text { National education } \\
\text { expenditure ( } 2001 \text { prices) }\end{array}$ & 40.5 & 43.1 & 54.3 & 48.8 & 52.9 & 74.9 & 80.7 \\
\hline $\begin{array}{l}\text { Growth in real national } \\
\text { education expenditure (\%) }\end{array}$ & 40.3 & 6.4 & 26.2 & -10.2 & 8.4 & 41.6 & 7.8 \\
\hline $\begin{array}{l}\text { Education expenditure } \\
\text { ( } \% \text { total of national } \\
\text { expenditure) }\end{array}$ & 11.4 & 14.3 & 16.0 & 14.0 & 13.9 & 16.9 & 17.2 \\
\hline $\begin{array}{l}\text { National education } \\
\text { expenditure ( } \% \text { of GDP) }\end{array}$ & 2.4 & 2.6 & 3.2 & 2.7 & 2.7 & 3.8 & 3.8 \\
\hline $\begin{array}{l}\text { Total nominal national } \\
\text { expenditure }\end{array}$ & 353.6 & 337.6 & 405.4 & 441.8 & 531.7 & 698.2 & 785.4 \\
\hline $\begin{array}{l}\text { Total real national } \\
\text { expenditure ( } 2001 \text { prices) }\end{array}$ & 353.6 & 301.8 & 340.0 & 348.9 & 380.0 & 442.4 & 468.3 \\
\hline $\begin{array}{l}\text { Government size (total } \\
\text { expenditure as \% of GDP) }\end{array}$ & 21.0 & 18.1 & 19.8 & 19.4 & 19.5 & 22.4 & 22.2 \\
\hline
\end{tabular}

* preliminary realisation of APBN and estimates for sub-national spending

** central government budget (APBN) and estimates for sub-national government

Source: World Bank (2007). 
Compared with its neighbouring countries, in Indonesia, total education expenditure is still relatively low. Table 8.3 illustrates public education expenditure in Indonesia and its neighbouring countries. This table shows how Indonesia's education expenditure is almost the same as other developing countries with a similar per capita income. The latest data from the World Bank's World Development Indicators (WDI) show that education expenditure as a percentage of total national expenditure in Indonesia, Malaysia and Thailand is 16.9 per cent, 27 per cent and 27 per cent, respectively.

Table 8.3 Education public expenditure in Indonesia and its neighbouring countries

\begin{tabular}{lllll}
\hline & Highest & & & Lowest \\
& & & & \\
\hline $\begin{array}{l}\text { Education public expenditure } \\
\text { as \% of total expenditure }\end{array}$ & $\begin{array}{l}\text { Malaysia } \\
27.0\end{array}$ & $\begin{array}{l}\text { Thailand } \\
27.0\end{array}$ & $\begin{array}{l}\text { Indonesia } \\
16.9\end{array}$ & $\begin{array}{l}\text { Philippines } \\
16.0\end{array}$ \\
& & & & \\
\hline $\begin{array}{l}\text { Education public expenditure } \\
\text { as \% of GDP }\end{array}$ & Malaysia & Thailand & Indonesia & Philippines \\
& 8.1 & 4.6 & 3.8 & 3.1 \\
\hline Total public expenditure as \% & Malaysia & Indonesia & Philippines & Thailand \\
of GDP (size of government & 29.7 & 22.4 & 19.6 & 16.8 \\
sector) & & & & \\
\hline GDP per capita (constant & Malaysia & Thailand & Philippines & Indonesia \\
2000 US\$) & 4290 & 2356 & 1085 & 906 \\
& & & & \\
\hline Population & Indonesia & Philippines & Thailand & Malaysia \\
& 217.6 & 81.6 & 63.7 & 24.4 \\
& & & & \\
\hline Percentage of population aged & Thailand & Indonesia & Malaysia & Philippines \\
O-14 & 4.1 & 3.5 & 3.0 & 2.8 \\
\hline & & & & \\
\hline
\end{tabular}

Source: World Bank (2007).

In Indonesia, the allocation of money to public education has been dominated by the basic education level. A recent study by the World Bank demonstrates education spending per program and level of government (Figure 8.10). As shown in the diagram, tertiary education received less than 10 per cent of education spending, while primary education (preschool, primary school and junior secondary) and middle or secondary education obtained about 75 per cent and 15 per cent of the total education budget, respectively. In this respect, the government policy seems to focus on the provision of basic education for the masses. 


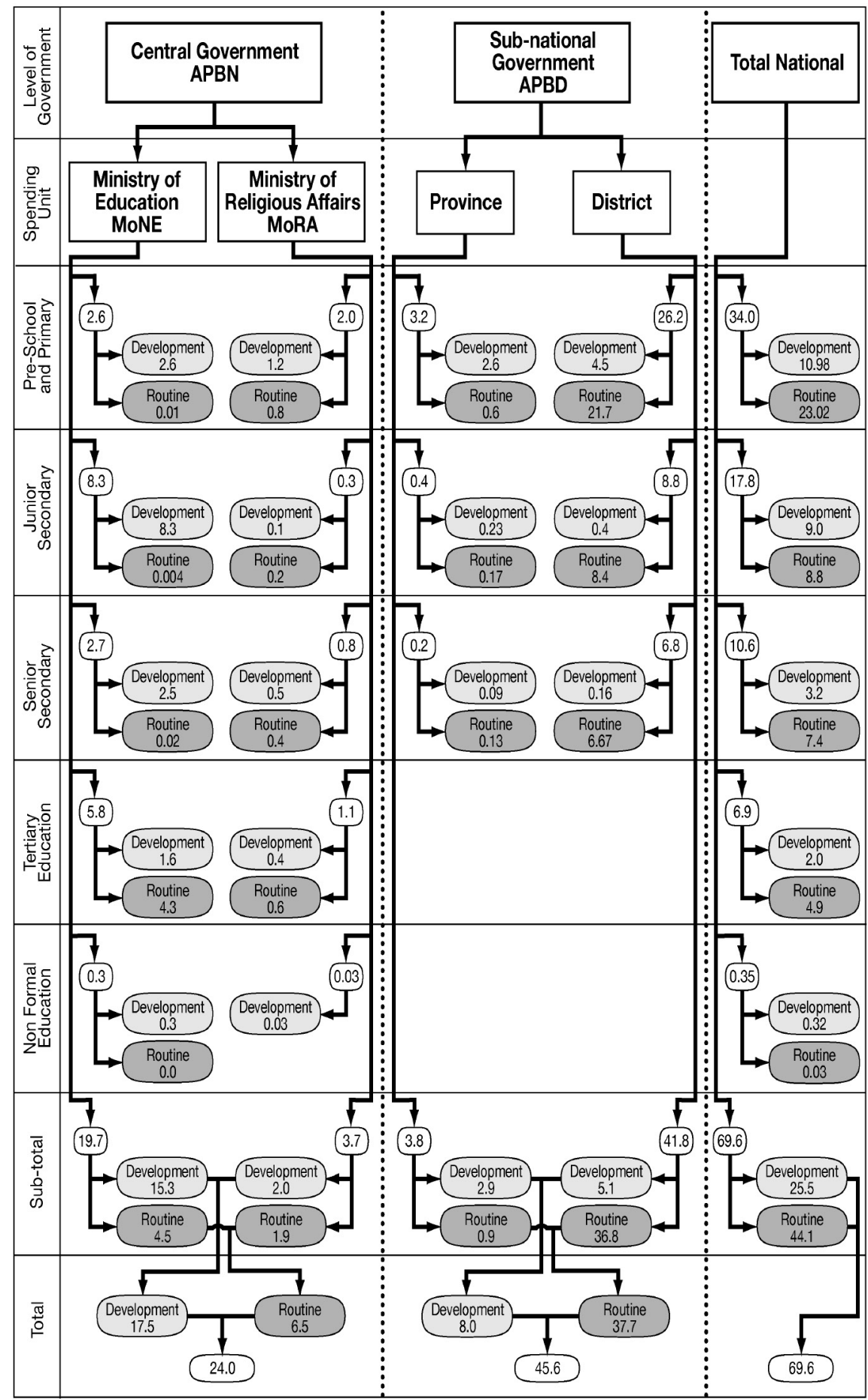

Figure 8.10 Education spending per program and level of government, 2004 
Compared with other countries in the Asia-Pacific, in Indonesia, the resources allocated to tertiary education are roughly similar. Table 8.4 reveals the public expenditure on higher education of some countries in the Asia-Pacific. As seen in the table, although it is below Australia and United States, the proportion of expenditure for higher education in Indonesia is higher than in Japan, Republic of Korea, Mexico and India. Indonesia's public expenditure per pupil as a percentage of GDP per capita is, however, the second-lowest in the group.

Table 8.4 Public expenditure on higher education of some countries in the Asia-Pacific

\begin{tabular}{|l|l|l|l|l|l|l|l|l|}
\hline & Australia & Indonesia & Japan & Malaysia & Korea & Mexico & $\begin{array}{l}\text { United } \\
\text { States }\end{array}$ & India \\
\hline $\begin{array}{l}\text { Public } \\
\text { expenditure } \\
\text { per pupil as } \\
\% \text { of GDP } \\
\text { per capita }\end{array}$ & 22.48 & 13.27 & 19.61 & 93.69 & 9.34 & 44.07 & 26.68 & 68.57 \\
\hline $\begin{array}{l}\text { Education } \\
\text { expenditure } \\
\text { on tertiary } \\
\text { education as } \\
\text { \% of total } \\
\text { educational } \\
\text { expenditure }\end{array}$ & 23.92 & 23.16 & 16.80 & 34.99 & 13.60 & 16.86 & 26.25 & 20.09 \\
\hline
\end{tabular}

Source: Fahmi (2007).

The largest part of the outlay of expenditure at the tertiary level goes to recurrent costs, such as salaries for academic and non-academic staff. Figure 8.11 illustrates the tertiary education expenditure by nature of spending during 2000-03. Based on this table, we can see that in that period, more than 80 per cent of tertiary education expenditure was spent for the current activities expenditure, while the remaining 20 per cent was used for capital expenditure. The capital expenditure consists of land acquisitions, university building development, and equipment purchases. 


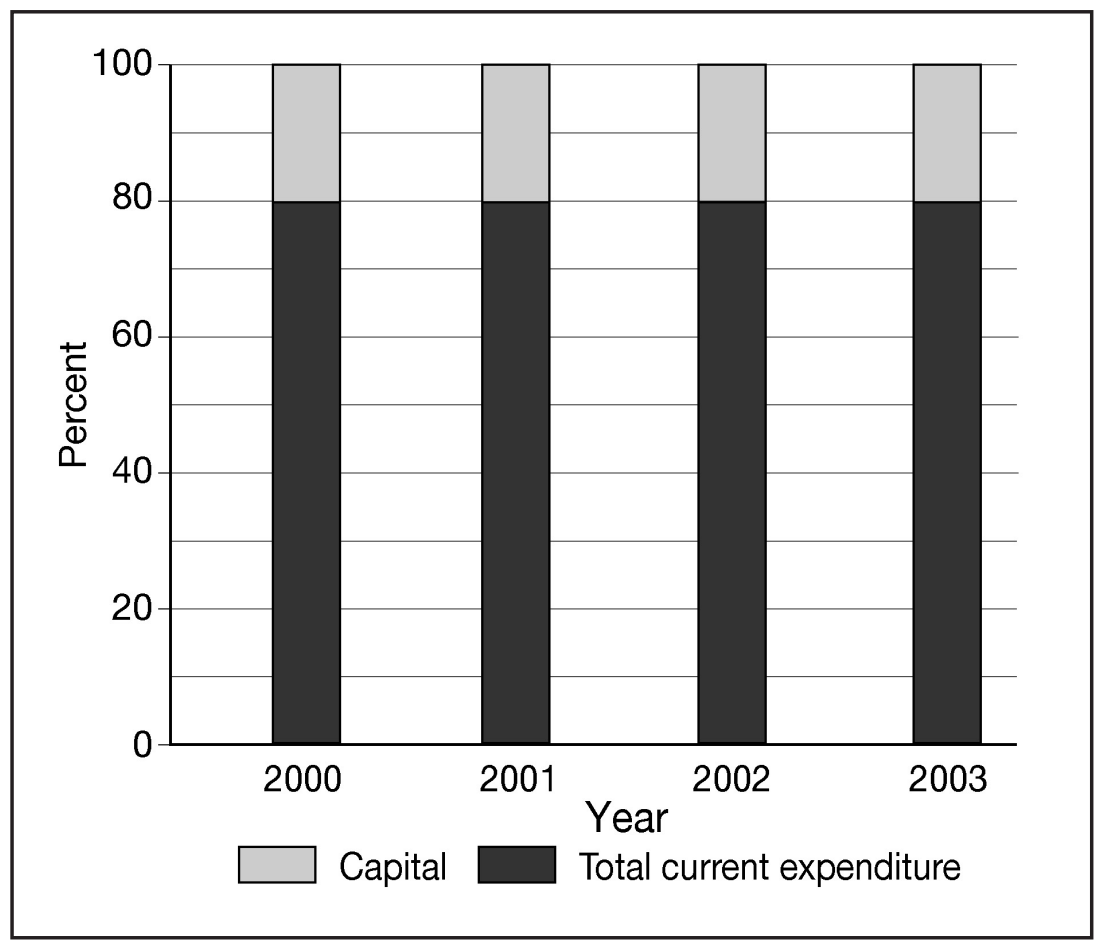

Figure 8.11 Tertiary education expenditure by nature of spending, 2000-03

Source: United Nations Educational, Scientific and Cultural Organisation.

\section{Student Fees, Student Loans and Scholarships}

Higher education expenses borne by parents and students vary greatly and depend on the degree taken, the study program, the status of the HEI and the location of the HEI. As a consequence of higher education reform, public HEIs may now set their own tuition fees, whereas they were previously set by the central government.

Table 8.5 illustrates the total higher education expenses borne by parents and students for undergraduate programs for the academic year 2004-05. The expenses for higher education cover not only tuition fees but also other items such as books, lodging, food, transportation and other personal expenses. In the academic year 2004-05, for example, the total cost carried by the parents and students of first degrees ranged from more than Rp6.8 million for the lower public HEIs to Rp20.8 million for the higher public HEIs, while it was about Rp31 million for private HEIs. 
Table 8.5 Higher education expenses borne by parents and students for a first degree, academic year 2004-05 (rupiah converted to US\$ by 2004 PPP estimate: \$1 = Rp2255)

\begin{tabular}{|c|c|c|c|c|}
\hline & & \multicolumn{2}{|c|}{ Public } & \multirow{2}{*}{$\begin{array}{c}\text { Private } \\
\text { High private }\end{array}$} \\
\hline & & Low public & High public & \\
\hline & $\begin{array}{l}\text { Special 'one-time' } \\
\text { or 'up-front' fees }\end{array}$ & & & \\
\hline \multirow{4}{*}{$\begin{array}{l}\text { Instructional } \\
\text { expenses }\end{array}$} & Tuition & $\begin{array}{r}\text { Rp300 } 000 \\
{[\$ 133]} \\
\end{array}$ & $\begin{array}{r}\text { Rp1 } 000000 \\
{[\$ 443]}\end{array}$ & $\begin{array}{r}\text { Rp4 } 000000 \\
{[\$ 1773]}\end{array}$ \\
\hline & Other fees & & & \\
\hline & $\begin{array}{l}\text { Books \& other } \\
\text { educational } \\
\text { expenses }\end{array}$ & $\begin{array}{r}R p 900000 \\
{[\$ 400]}\end{array}$ & $\begin{array}{r}\text { Rp1 } 350000 \\
{[\$ 598]} \\
\end{array}$ & $\begin{array}{r}\text { Rp2 } 250000 \\
{[\$ 997]} \\
\end{array}$ \\
\hline & $\begin{array}{l}\text { Subtotal expenses } \\
\text { of instruction }\end{array}$ & $\begin{array}{r}\text { Rp1 } 200000 \\
{[\$ 532]}\end{array}$ & $\begin{array}{r}\text { Rp2 } 350000 \\
{[\$ 1042]}\end{array}$ & $\begin{array}{r}\text { Rp6 } 250000 \\
{\left[\begin{array}{l}\$ 2770]\end{array}\right.}\end{array}$ \\
\hline \multirow{6}{*}{$\begin{array}{l}\text { Student living } \\
\text { expenses }\end{array}$} & Lodging & $\begin{array}{r}\text { Rp900 000 } \\
{[\$ 400]} \\
\end{array}$ & $\begin{array}{r}\text { Rp9 } 000000 \\
{[\$ 3990]}\end{array}$ & $\begin{array}{r}\text { Rp10 } 800000 \\
{[\$ 4790]}\end{array}$ \\
\hline & Food & $\begin{array}{r}\text { Rp3 } 600000 \\
{[\$ 1596]}\end{array}$ & $\begin{array}{r}\text { Rp6 } 300000 \\
{[\$ 2793]}\end{array}$ & $\begin{array}{r}\text { Rp8 } 100000 \\
{[\$ 3592]}\end{array}$ \\
\hline & Transportation & $\begin{array}{r}\text { Rp315 } 000 \\
{[\$ 140]} \\
\end{array}$ & $\begin{array}{r}\mathrm{Rp} 450000 \\
\$ 200] \\
\end{array}$ & $\begin{array}{r}\text { Rp2 } 250000 \\
{[\$ 997]} \\
\end{array}$ \\
\hline & $\begin{array}{l}\text { Other personal } \\
\text { expenses }\end{array}$ & $\begin{array}{r}\text { Rp800 } 000 \\
{[\$ 354]} \\
\end{array}$ & $\begin{array}{r}\text { Rp2 } 700000 \\
{[\$ 1197]}\end{array}$ & $\begin{array}{r}\text { Rp3 } 600000 \\
{[\$ 1,596]}\end{array}$ \\
\hline & $\begin{array}{l}\text { Subtotal expenses of } \\
\text { student living }\end{array}$ & $\begin{array}{r}\text { Rp5 } 615000 \\
{[\$ 2490]} \\
\end{array}$ & $\begin{array}{r}\text { Rp18 } 450000 \\
{[\$ 8180]} \\
\end{array}$ & $\begin{array}{r}\text { Rp24 } 750000 \\
{[\$ 10975]}\end{array}$ \\
\hline & $\begin{array}{l}\text { Total cost to } \\
\text { parent \& student }\end{array}$ & $\begin{array}{r}\text { Rp6 } 815000 \\
{[\$ 3022]}\end{array}$ & $\begin{array}{r}\text { Rp20 } 800000 \\
{[\$ 9223]}\end{array}$ & $\begin{array}{r}\text { Rp31 } 000000 \\
{\left[\begin{array}{lll}\$ 13 & 747]\end{array}\right.}\end{array}$ \\
\hline
\end{tabular}

Low public: low public tuition, living at home with parents.

High public: high public tuition, living as 'independent adult'.

High private: high private tuition, living in dormitory or shared apartment.

Source: Collected from web sites of Indonesian universities, 2005 (quoted from World Bank 2007).

This high level of expenses would have an adverse effect on students coming from a poor family background. To help disadvantaged students, the government works closely with HEIs to provide financial assistance schemes in the form of scholarships. Before the recent reform in higher education, scholarship programs allocated to students in private HEIs were relatively limited. Yet a recent policy change has increased the allocated funds for scholarships to private HEIs; however, students of public HEIs are still the larger beneficiaries. Based on our interview with a government official, about 25 per cent of the total government scholarship program is allocated to students at private HEIs. Instead of giving directly to private institutions, as the government does to public HEIs, the government allocates the funds to the Koordinasi Perguruan Tinggi Swasta (Kopertis; Coordination of Private Higher Education Institution), and the Kopertis authority then allocates the funds amongst its members. Kopertis itself is a network of private HEIs with only private HEIs as its members. 
The government offers three types of scholarship: for student achievement in academic activities; a social safety net scholarship provided by compensation from the oilsubsidy reduction; and for student achievement in sport and cultural activities. In principle, all the scholarship schemes are targeted at disadvantaged students. The government has granted the universities a full set of criteria for recipient students and to manage the distribution of the funds. The amount of the scholarship itself is about Rp250 000 per month per student (US\$25), which covers tuition fees and a living allowance, regardless of which HEI the student attends.

In addition, the universities cooperate with other institutions, such as private enterprises, foundations and alumni associations, to provide scholarships. Unlike scholarships from the government, scholarships from these other institutions vary regarding their schemes and criteria. These scholarship programs are given not only to disadvantaged students, but also to students who meet other criteria. Tanoto Foundation - which provides scholarships - targets its scholarships at intelligent students with potential leadership qualities but who face financial difficulties.

These scholarships are granted not only for undergraduates but also for graduate students. They cover tuition fees and an allowance. The scholarship may also be extended to research funding, though case-by-case criteria apply. For undergraduate students, the foundation granted Rp500 000 a month for a living allowance given directly to the individual student's bank account and up to Rp3 million a semester for tuition fees. About 300 undergraduate students and 50 graduate students have received scholarships from Tanoto Foundation. These students have been limited to only six public universities.

Parallel with scholarships, the government is now planning to create a student loan program and a voucher program for disadvantaged students that will cover their tuition costs. The Ministry of National Education introduced student loans in the early 1980s and what was called 'Kredit Mahasiswa Indonesia' (KMI; Indonesian Student Loan). The high default rate, however, made the student loan program unsustainable. According to our interview with several key people, the default rate reached 95 per cent. Unfortunately, there are no available data that can help evaluate this program. By the end of the 1980s, the government ended the student loan program.

The failure of the KMI was due to poor administration. Many recipient students did not repay their loan after finishing their studies. The banks giving the loan had poor administration, which failed to monitor and trace the graduates. The banks treated the student loans like grants since they thought it was part of the government's development program from the central bank, the Bank of Indonesia. This poor loan management was recorded as a non-performing loan and student loans have been perceived by the banking sector as a high-risk business. This has meant banks are reluctant to once again engage in this program. 
By 2006, a private education foundation called Sampoerna Foundation redesigned the student loan program. In designing the program, the foundation cooperated with the International Finance Corporation (IFC) and Bank International Indonesia (BII) as creditors. The scheme essentially is a risk-sharing mechanism to leverage contributions from the foundation into a portfolio of student loans (IFC 2006). In this program, BII acts as an administrator of the program. According to an estimate, the total budget of the student loan program was almost US\$20 million, with half of the fund supported by the IFC.

Based on our interview with a high-ranking manager of Sampoerna Foundation, the organisation previously focused only on the scholarship program, but it now designs the first private-supported student loan scheme. The decision to promote the student loan program was encouraged by the fact that many potential students who do not have long-term financial difficulties cannot go to college because of cash-flow problems. Their main financial problem usually is up-front fees, which are very large.

The loan is characterised as one without any collateral, although the student or their family members who act as guarantor are required to be 'bankable' (they must have a job and minimum earnings of Rp40 million a year). The loan cap provided by the foundation ranges from Rp10 million to Rp200 million, while the maximum loan that can be given is up to five times the student's or their family member's net income per month. The bank charges interest of 1.5 per cent a month, with a repayment period ranging from six months to three years.

This student loan program is different from a typical program in other countries, particularly regarding the payment method. The program is best described as a mortgage loan in which students, or the parents of the student, have to repay the loan every month after the first disbursement of the loan. Sampoerna Foundation helps students with short-term cash-flow problems.

Since the program's launch in 2007, the number of students receiving a loan is about 15 , suggesting that the program covers very limited recipients. This limitation is due not only to the short period of program implementation, but also to the institutional or regulatory restrictions. From the institutional or regulatory aspect, banks still perceive student loans as very risky and there is no strong incentive given from the government or the central bank for banks to lend money to a student loan program.

\section{Recent Major Policy: Higher education reform}

Due to increasing globalisation and internationalisation pressures, the government has taken a number of measures in the past decades to improve the quality, efficiency and relevance of higher education in Indonesia. The first initiative started in 1994, when the government through the DGHE formed 
the Higher Education Strategy Task Force - assigned to develop a strategy for higher education in Indonesia for the next few decades. The task force introduced 'The New Paradigm' for higher education management based on quality, autonomy, accountability, accreditation and evaluation. This new paradigm has significantly altered the mode of individual HEI operation and the overall legal, regulatory and financial controls.

\section{Structure and Institutional Reform}

As part of the paradigm shift to strengthen institutional capacity at the centre as well as at individual universities, the DGHE established the Board of Higher Education (DPT), with three councils (education, research, and development) and the National Accreditation Board for Higher Education (BAN-PT). The DPT has responsibility to provide strategic recommendations and to act as the bridge between the DGHE and external funding bodies as well as between the DGHE and the universities that receive competitive grants. BAN-PT is mandated to independently arrange and conduct the accreditation of academic programs at private and public HEIs. BAN-PT aims to improve the transparency of the higher education system in Indonesia, to guide consumers, to guarantee accountability, and to strengthen incentives for individual universities to raise quality standards, efficiency and relevance. Based on the National Education Act No. 2/1989 and Government Regulation on Higher Education No. 60/1999, BAN-PT is the only accreditation body in Indonesia's higher education system. BAN-PT, mandated by Ministerial Decree 188/U/1998, since 2001 has accredited all programs in HEIs, both public and private.

By 1999, the government also issued a new government regulation (PP 61/1999) that set out the mechanism to transform state/public HEIs into autonomous universities called 'State Legal Entity Universities' (Universitas Badan Hukum Milik Negara; BHMN). The government asked the four most established public HEIs (University of Indonesia, University of Gajah Mada, Institut Teknologi Bandung and Institut Pertanian Bogor) to pioneer the transformation. In December 2000-based on government regulations PP 152, 153, 154 and $155 / 2000$ - those four universities formally changed to become new public legal entity universities.

Since the transformation, the universities are no longer part of the government bureaucracy and, consequently, they are responsible more to the public rather than to the Ministry of National Education. Similar to reforms in Latin America, here, by creating a 'para-market relationship', the government provides the operational cost in the form of a block grant based on the performances of the HEIs. In addition, university management is structured more like a corporate system. In the university transition plans, all staff who used to be civil servants 
become university employees within 10 years. As argued by Susanto and Nizam (2004), however, the inadequate support for legal and financial measures has hindered the reform from effectively embedding into the entire system.

\section{Competitive Funding Schemes}

Along with the institutional and structural changes, the new paradigm has also changed financial aspects of HEIs. The new paradigm has given individual public HEIs the power and responsibility to work as if they were private-sector institutions. Individual public HEIs are required to conduct self-evaluation, prepare institutional development plans based on their own particular needs, and arrange budgets according to their projected resources and priority needs in order to receive investment funds from the central government. Supported by loans from the World Bank and the Asian Development Bank (ADB), the government also initiated several competitive funding schemes as a mechanism for allocating its funds to universities.

Before the government launched the new competitive fund scheme-which has opened opportunities for private HEIs to participate - there were large differences between the funding mechanisms of private and public HEIs. In the past, the government supported very limited funding for private institutions. The major cause of this is the very limited budget allocation from the state budget and the large publicly funded HEIs. Public HEIs have relied on their recurrent and development government budgets for their funding, while private HEIs relied on student fees and contributions from external sources. Bray and Thomas (1998) estimate that about 87.92 per cent of the government budget for higher education (about Rpl.3 billion) went to public HEIs in the period 1995-96. This allocation funded about 853 students enrolled in public HEIs. For the same period, only 3.8 per cent of funding from both the recurrent and the development budgets went to private HEIs, which enrolled 58 per cent of total students. The remainder of the allocation went to Islamic HEIs.

The competitive funding schemes were initially implemented by the introduction of the University Research for Graduate Education (URGE) project, in 1994. The project has, however, been limited to public HEIs. URGE was implemented through a competitive funding process to develop research capacity for the units conducting postgraduate programs.

In 1996, the DGHE introduced the first special competitive grants through the Development of Undergraduate Education (DUE) project, covering all disciplines, courses and study programs. This project aimed to advance the educational quality of undergraduate programs. It is targeted at 17 of the leastestablished public HEIs, which have not seen any major investment in the past five to 10 years. The funding for universities is granted on a competitive basis 
according to proposals from the universities. The funding was granted under a block-grant contract and the granted HEIs were required to match funds in the amount of 5 per cent of the total grant. The funds were distributed to a particular account of the institutions, in order to reduce the existing bureaucratic structures. Tadjudin (2007) explains that the evaluation of the DUE project was more complicated than those in the URGE projects since the evaluation of education projects involves more qualitative performance indicators compared with the evaluation of research projects. In addition, unlike in the evaluation of research projects, in education projects, there are many dimensions that need to be identified.

During 1998-2004, the DGHE introduced the second competitive funding program, called the Quality for Undergraduate Education (QUE) project- 80 per cent of which was funded by a World Bank loan. Like the DUE project, this project aimed to enhance undergraduate education. Unlike the DUE project, however, which was open only to public HEIs, the QUE project was open to private HEIs as well. The QUE project was an open bidding process based on a proposal submitted by a study program, and the merit of the proposal was essential for success. The main performance indicators of this project covered the areas of leadership, relevance, academic atmosphere, institutional management, sustainability, efficiency and productivity (L-RAISE). Each grant was valued about US\$1.8 million, which was provided for five-year institutional development programs. Nizam (2006) explains that the project was highly competitive and attracted many applicants, as illustrated in Table 8.6. Furthermore, he argues that this funding mechanism has been considered one of the most significant reforms in financing HEIs since it gives a sense of ownership and direct accountability to the recipient institutions.

Table 8.6 The Quality Undergraduate Education (QUE) funding project

\begin{tabular}{l|l|l|l|l}
\hline & $\begin{array}{c}\text { Pre-proposals } \\
\text { submitted }\end{array}$ & $\begin{array}{c}\text { Selected for } \\
\text { full proposals }\end{array}$ & $\begin{array}{c}\text { Selected for } \\
\text { site visit }\end{array}$ & Funded \\
\hline Batch 1 (1998) & 317 & 45 & 25 & 16 \\
Batch 2 (1999) & 250 & 51 & 27 & 14 \\
Batch 3 (2000) & 249 & 61 & 26 & 16 \\
\hline
\end{tabular}

Source: Nizam (2006).

Pursuing the success of the QUE project, the government adopted this model as a mechanism for transferring its funding to HEIs. As a consequence, the government has introduced several other competitive funding schemes, including the DUE-like project, the Semi-QUE project, and the Competitive Funding Program (PHK). These competitive funding schemes are directed towards achieving certain targets as measured by performance indicators 
that have been decided and made by the grantees. The DUE-like project was introduced in 1999. This project was analogous with the DUE project, except that the source of funding was government funds. In the same vein, the SemiQUE project that was launched at the same time as the DUE-like project was financed wholly by government funds. This project was similar to the QUE project with more weight given to entrepreneurship development. Like the QUE project, here, the government used the L-RAISE criteria in selecting the proposal process for the funding. The PHK project was introduced in 2001, and was also funded by the government in order to continue the quality improvement of HEIs. The project was divided into four program categories: PHK-Al focused on the advancement of management and organisational health for units involved in running educational programs; PHK-A2 emphasised the improvement of internal efficiency at the departmental level; PHK-A3 stressed the importance of enhancing a graduate's skills and competencies; and PHK-AB focused on the ability of departments to develop competitive programs.

In addition, the ADB adopted a similar competitive funding scheme in the region when it supported the Indonesian government to launch the Technological and Professional Skills Development Project (TPSDP) in 2001. This project used the same evaluation criteria as the QUE project, but with some additional criteria, including access and equity. This project aims mainly to improve the relevance of the learning outcomes and to advance the professionalism of graduates. The project was directed to both public and private institutions, except for autonomous universities. The loan from the ADB contributed about 80 per cent of funding, while the rest came from the government (12 per cent) and institutional matching funds from the HEIs ( 8 per cent).

\section{The Reform and its Impact on Financing: HEI perspectives}

The reform has brought significant changes in the financing mechanisms at the HEI level, particularly to public HEIs that relied a lot on government support. Recent findings show an adverse trend in which public HEIs are becoming more reliant upon student fees because of the reform. As a result, public universities have responded to the limited funds by offering professional and vocational programs. In these programs, they usually charge higher tuition fees compared with academic programs (Welch 2007). In the teaching activities, these institutions open less-demanding academic programs with high tuition fees, creating new professional and vocational programs. In nonteaching activities, they commercialise the institution's infrastructure. These institutions, as a result of reduced subsidies, have increased tuition fees and additional admission fees for regular academic students. For example, in the 1998-99 academic year, the tuition fee at the University of Indonesia- one 
of the HEIs involved in the project - was about Rp550 000. By the 2000-01 academic year, the tuition fee increased almost threefold for social sciences. An additional admission fee, even though voluntary, is asked for at the beginning of the academic year, particularly for medical and engineering schools.

The impact of the financing reform is now strongly felt by HEIs that have been involved in the pilot project of the reform. Those HEIs are the University of Indonesia (UI), Institut Pertanian Bogor (IPB), University of Gadjah Mada (UGM) and Institut Teknologi Bandung (ITB). After nearly a decade, these HEIs still seek the best formats and practices. Figure 8.12 illustrates significant changes in income sources for University of Indonesia- one of the most established public HEIs in Indonesia. There is a declining trend of government support for University of Indonesia. In 1994, income from the government accounted for about 81 per cent $(28.5$ per cent from the recurrent budget and 52.5 per cent from the development budget). In 1999, the trend was reversed: self-generated and external sources began to replace the government budget, which accounted for 46.7 per cent of total income. By 2006, income from the development budget shrank considerably - to only 2.7 per cent of the total; meanwhile, self-generated and external source contributions increased to 80.2 per cent .

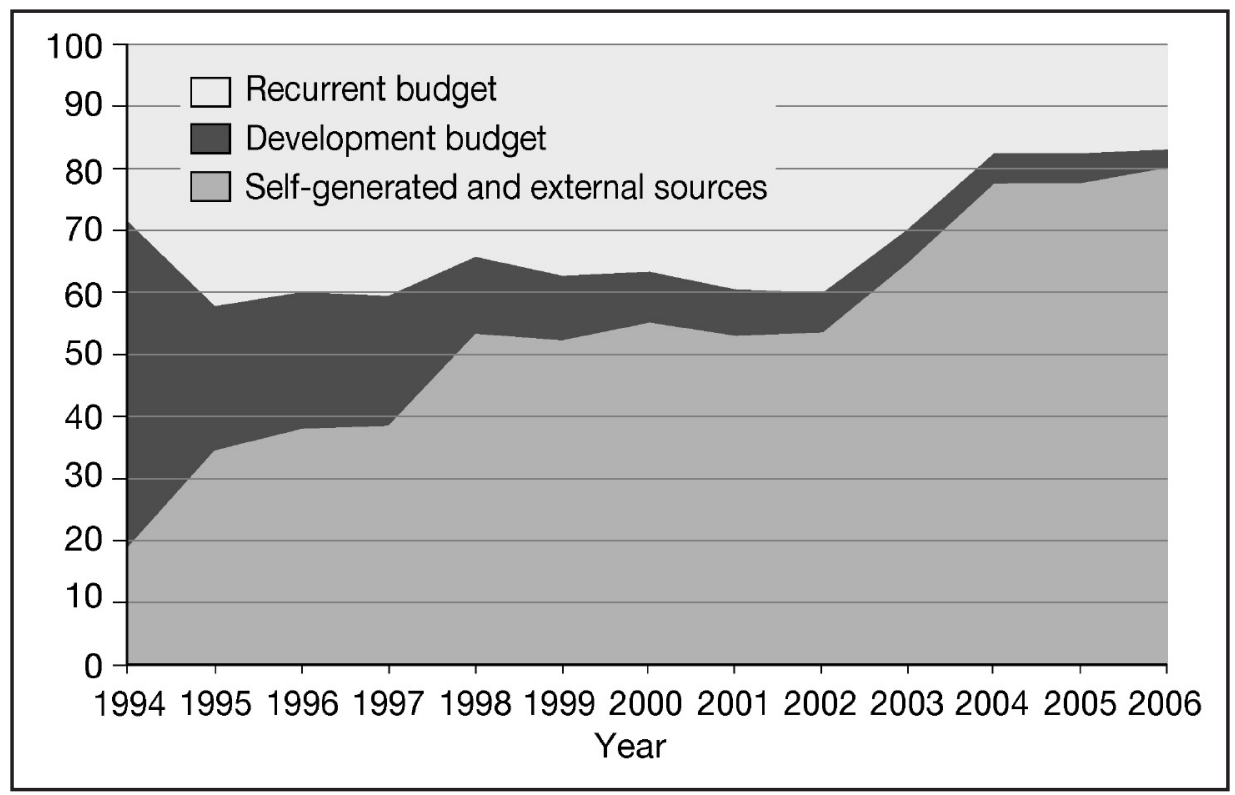

Figure 8.12 Composition of University of Indonesia's income sources

Source: Universitas Indonesia 2003, UI dalam Angka. 


\section{Conclusion}

Indonesia's universities have a short history. During the past few decades, we have seen a rapid expansion of the higher education sector. This development has not, however, been followed by proper long-term planning, vision or good funding mechanisms. The universities have suffered internal inefficiency, poor initiatives (particularly in research) and lack of public accountability. Undoubtedly, these problems have had negative impacts on quality, efficiency and the relevance of higher education in Indonesia.

Facing these issues, the government, through the Directorate-General for Higher Education (DGHE), has undertaken major reform in order to improve the quality, efficiency and relevance of higher education in Indonesia. Some key points of the reform are the autonomy of university governance, its funding mechanism, the relationship between private and public HEIs, and the curriculum content that is set in line with the national development context. The reform has brought about considerable challenges for HEIs, particularly regarding financial matters, though it also offers opportunities in the context of independence and autonomy. After a decade, Indonesia's universities still seek the best format and practices so that they are best equipped to face the challenges of the future.

\section{References}

Bray, M. and Thomas, R. M. (eds) 1998, Financing of Education in Indonesia, Asian Development Bank, Manila.

Buchori, M. and Malik, A. 2004, 'Higher education in Indonesia', in P. Altbach and T. Umakoshi (eds), Asian Universities. Historical perspectives and contemporary challenges, The Johns Hopkins Press, Baltimore, pp. 249-78.

Davies, J. 2002, Empirical evidence on human capital externalities, RBC Financial Group Economic Policy Research Institute Working Papers No. 20035, University of Western Ontario, London, Ontario.

Directorate-General of Higher Education (DGHE) 2003, Basic framework for higher education development KPPTJP IV (2003-2010), Technical Report, Directorate-General of Higher Education, Ministry of National Education, Jakarta.

Fahmi, M. 2007, Indonesian higher education: the chronicle, recent development and the new legal entity universities, Working Paper in Economics and Development Studies No. 200710, October, Department of Economics, Padjadjaran University, Bandung, Indonesia. 
International Finance Corporation (IFC) 2006, Sampoerna Student Financing Facility: Summary of proposed investment, International Finance Corporation, Washington, DC, viewed 9 June 2008, <http://www.ifc.org/ifcext/ spiwebsitel.nsf/2bc34f011b50ff6e85256a550073fflc/bfa7100ccf2cdb6f8525 719c0055cfeb?opendocument>

Moeliodihardjo, et al. 2000, Higher education strategy: implementation of the new paradigm, Background paper for university autonomy.

Moretti, E. 1998, Social return to education and human capital externalities: evidence from cities, Institute for Research on Labor and Employment Working Papers, University of California, Berkeley.

Nizam 2006, 'Indonesia: the need for higher education reform', in Higher Education in South-East Asia, UNESCO Asia and Pacific Regional Bureau for Education, Bangkok, pp. 35-68.

Purwadi, A. 2001, 'Impact of economic crisis on higher education in Indonesia', in N. V. Varghese (ed.), Impact of the Economic Crisis on Higher Education in East Asia: Countries' experiences, IIEP/UNESCO, Paris, pp. 61-75.

Triaswati, N. and Roeslan, F. 2003, Senior Secondary Education and Access to Higher Education, Higher Education Sector Study, Japan Bank for International Cooperation/Directorate-General of Higher Education, Jakarta.

Universitas Indonesia 2003, UI dalam Angka.

Welch, A. R. 2006, 'Blurred vision?: public and private higher education in Indonesia', Springler Science + Business Media B.V., July. 